\title{
Presence of dual diagnosis between users and non-users of licit and illicit drugs in Brazil
}

\author{
Presença de diagnóstico duplo entre usuários e não \\ usuários de drogas lícitas e ilícitas no Brasil
}

Mariana Bandeira Formiga', Selene Cordeiro Vasconcelos', Melyssa Kellyane Cavalcanti Galdino², Murilo Duarte da Costa Lima'

\begin{abstract}
Objective: Investigate the occurrence of dual diagnosis in users of legal and illegal drugs. Methods: It is an analytical, cross-sectional study with a quantitative approach, non-probabilistic intentional sampling, carried out in two centers for drug addiction treatment, by means of individual interviews. A sociodemographic questionnaire, the Alcohol, Smoking and Substance Involvement Screening Test (ASSIST) and the Mini-International Neuropsychiatric Interview (MINI) were used. Results: One hundred and ten volunteers divided into abstinent users (group 1), alcoholics (group 2) and users of alcohol and illicit drugs (group 3). The substances were alcohol, tobacco, crack and marijuana. A higher presence of dual diagnosis in group 3 (71.8\%) was observed, which decreased in group 2 (60\%) and 37.1\% of drug abstinent users had psychiatric disorder. Dual diagnosis was associated with the risk of suicide, suicide attempts and the practice of infractions. The crack consumption was associated with the occurrence of major depressive episode and antisocial personality disorder. Conclusion: It was concluded that the illicit drug users had a higher presence of dual diagnosis showing the severity of this clinical condition. It is considered essential that this clinical reality is included in intervention strategies in order to decrease the negative effects of consumption of these substances and provide better quality of life for these people.
\end{abstract}

\section{RESUMO}

Objetivo: Investigar a ocorrência do diagnóstico duplo entre os usuários de drogas lícitas e ilícitas. Métodos: Estudo analítico, transversal, com abordagem quantitativa, amostragem não probabilística do tipo intencional, realizado em dois centros de tratamento para a dependência química, por meio de entrevista individual. Utilizaram-se um questionário sociodemográfico, o Teste de Triagem do Envolvimento com Álcool, Tabaco e Outras Substâncias (ASSIST) e o Mini-International Neuropsychiatric Interview (MINI). Resultados: Cento e dez voluntários divididos em abstinentes (grupo 1), alcoolistas (grupo 2) e usuários de álcool e drogas ilícitas (grupo 3). As substâncias mais consumidas foram álcool, tabaco, crack e maconha. Observou-se maior presença de diagnóstico duplo no grupo 3 (71,8\%),

1 Federal University of Pernambuco (UFPE), Department of Neuropsychiatry, Recife, PE, Brazil. 2 Federal University of Paraíba (UFPB), Department of Psychology, João Pessoa, PB, Brazil. 


\section{Palavras-chave}

Transtorno por uso de substâncias, usuários de drogas, diagnóstico duplo, comorbidade psiquiátrica. decrescendo no grupo 2 (60\%) e 37,1\% dos abstinentes de drogas apresentaram transtorno psiquiátrico. O diagnóstico duplo foi associado a risco de suicídio, tentativas de suicídio e prática de atos infracionais. O consumo do crack foi associado à ocorrência do episódio depressivo maior e ao transtorno de personalidade antissocial. Conclusão: Os usuários de drogas ilícitas apresentaram maior presença do diagnóstico duplo, evidenciando a gravidade desse quadro clínico. Considera-se imprescindível que essa realidade clínica seja incluída nas estratégias de intervenção, com o intuito de minimizar os prejuízos decorrentes do consumo dessas substâncias e proporcionar melhor qualidade de vida a essas pessoas.

\section{INTRODUCTION}

The substance use disorder (SUD) refers to the pathological pattern of behavior related to licit and illicit drugs'. The World Health Organization (WHO), through the United Nations Office on Drugs and Crime, identified that substance use has increased in proportion with population growth? From the world's population, two billion drink alcohol ${ }^{3}$ and $5 \%$ use illicit drugs².

In the European Union (EU) one quarter of the adult population consumed illicit drugs, most of them using marijuana, followed by cocaine, amphetamine and ecstasy ${ }^{4}$. In the United States found that 39\% of young people consume alcohol excessively and $21 \%$ use other drugs and, marijuana, painkillers, cocaine and heroin are the most used ${ }^{5}$. In Brazil, the most consumed illicit drugs were marijuana, cocaine, stimulants and crack ${ }^{6}$, and Brazilian average alcohol consumption is higher than the global average ${ }^{2}$.

Concomitant to substance use disorder, psychiatric disorders (PD) may occur, characterizing dual diagnosis ${ }^{7}$ (DD). The presence of only one of these disorders - the PD or SUD - increases the probability of the DD by 20 times $^{8}$.

In Europe it is estimated that $80 \%$ of drug users have a dual diagnosis 9 . In the United States, the Epidemiologic Catchment Area Study ${ }^{10}$ (ECA) revealed that the most frequent dual diagnosis was of anxiety and mood disorders, 28\% and $26 \%$, respectively, of the analyzed cases. In Brazil, the II LENAD $^{6}$ identified higher prevalence of anxiety, followed by depression, with $23.9 \%$ and $15.1 \%$, respectively.

People with DD presented a more severe clinical condition $^{7,11,12}$, have more resistance to treatment ${ }^{11}$ and less successful results ${ }^{11,13,14}$, have greater psychosocial problems $s^{11,15}$, use health services more frequently, present risk of suicide $^{11,12,14,16,17}$, violent behavior ${ }^{11,16}$ and involvement in crimes ${ }^{11}$, besides having a worse prognosis than those with single diagnosis ${ }^{15}$ and higher costs to health services than individuals only with SUD ${ }^{14}$.

Neurogenic changes in the hippocampus have sustained etiological hypothesis of common biological factors between addiction and drug use disorder, which has strengthened the studies on dual diagnosis. It is considered that there is a two-way relationship, in which the low-neurogenic activity states of the hippocampus increase vulnerability to both disorders, what helps to explain why drug addiction usually worsens when concomitant psychiatric syndromes occur ${ }^{18}$.

Although dual diagnosis has been broadly investigated, studies concerning this were not found, in the literature, in data collection of this study. In this sense, the objectives of this research were to investigate the occurrence of dual diagnosis in users of the legal and illegal drugs and compare the presence of DD between users and non-users of substances and correlate with socio-demographic variables. The hypothesis formulated was that the most consumed substances were alcohol and marijuana; and users of illegal drugs present a higher presence of dual diagnosis, being anxiety disorders and mood disorders the most frequent.

\section{METHODS}

This is an analytical, cross-sectional study with a quantitative approach, non-probabilistic intentional sampling. It was carried out in two reference centers specialized in drug addiction treatment (Psychosocial Care Center for Alcohol and Other Drugs - (APSad), in the metropolitan region of João Pessoa, Paraíba, Brazil, approved by the Ethics Committee, CAAE no 498,403.

This was a convenience and nonprobability sampling composed of 110 volunteers. For data collection, selected users of CAPSad were invited to participate in this research, but only those who showed interest and filled in samples' criteria for inclusion and exclusion answered to the instruments. Users from both sexes were able to be part of this stu$d y$, but only the ones over 18 years old. Users who were under the influence of substances and/or presented psychotic break that would prevent the application of the instruments were excluded from this research.

Data collection was conducted through individual interviews, lasting an average of fifty minutes. A sociodemographic questionnaire developed by the authors was used together with the Alcohol, Smoking and Substance Involvement Screening Test (ASSIST) and the Mini International Neuropsychiatric Interview (MINI). There was some training with standard examiner for applying the ASSIST and the MINI.

The ASSIST is an easy application questionnaire, developed by the World Health Organization (WHO) in 2002, 
which evaluates the consumption pattern of nine classes of psychoactive substances (tobacco, alcohol, marijuana, cocaine, stimulants, sedatives, inhalants, hallucinogens and opiates) based on the consumption of the last three months ${ }^{19}$.

The Brazilian version of ASSIST has presented significant scores positively correlated with other measures of use, abuse or dependence (i.e., MINI-Plus and the "Addiction Severity Index" - AIS), good sensitivity, specificity, internal consistency and validity ${ }^{20}$.

In order to identify psychiatric disorders, risk and suicides attempts, we used the diagnostic Mini International Neuropsychiatric Interview ${ }^{21}$ (MINI), translated and adapted to Brazilian population and compatible with DSM-III-R/IV and ICD-10. It is noteworthy that by the time of data collection for this research no interview using the MINI standards based on the criteria of the Diagnostic and Statistical Manual of Mental Disorders 5 (DSM-5) was published.

\section{Data analysis}

Data analysis was performed from a database in the Statistical Package for Social Sciences (SPSS) version 21. Descriptive analysis included the measures of central tendency (mean), dispersion (standard deviation), and frequency percentages. The inferential analysis was by means of Pearson's chi-square $\left(\chi^{2}\right)$ and Poisson Regression. The robust estimator was employed to reduce the error of the models and in multivariate regressions the input Stepwise method was adopted. The significance accepted was less than or equal to 0.05 .

\section{RESULTS}

The sample consisted of 110 volunteers, aged 18 to 69 years, with a mean age of 41.73 years ( $S D \pm 12.25$ ), which were divided into three groups. Group 1, consisting of the respondents who are in abstinence from alcohol and illegal drugs for at least three months; group 2, with alcoholics; and group 3, with alcohol and illicit drug users.

As for the sociodemographic profile (Table 1), it was identified that the majority were male, black, with up to 9 years of study, without a fixed personal financial income. In groups 1 and 3, they were mostly unmarried, unemployed and in group 2 they were separated/divorced with some kind of labor occupation.

The majority of the sample had previous treatment for chemical dependency in another service and is using the current service more frequently than three days a week. The involvement with illegal acts, defined in this study as having been arrested or detained, increased from group 1 to 3 .

Most of the sample started the consumption of substances under the influence of friends $(80.9 \% ; n=89)$ and has relatives who are users (85.5\%; $n=94)$. The first drug used was alcohol $(71.6 \%, n=78)$, followed by cigarettes $(48.2 \%, n=53)$ and marijuana $(10 \% ; n=11)$. The average age of the first alcohol consumption was 15.22 years (SD 5.88) 15.85 cigarette (PD = 7.13) and other drugs at the age of 15.68 (SD 4.07).

The most consumed substances were alcohol (67.3\%; $n=74)$, tobacco $(60 \% ; n=66)$, $\operatorname{crack}(30 \% ; n=33)$ and marijuana $(27.3 \% ; n=30)$. The majority $(92.7 \% ; n=102)$ have never used injection drugs. For tobacco, in group 1, 40\% $(n=14)$ used it, in group 2, 50\% $(n=18)$ and group $3,87.2 \%(n=34)$ were smokers. From the illicit drug users $(n=42), 42.8 \%$ ( $n=$ 18) used only one drug and $57.2 \%(n=24)$ were polyusers.

The risk of suicide and attempted suicides and the presence of the double diagnosis are described in Table 2. Regarding the presence of psychiatric disorders in survey respondents, it was observed that, $20 \%(n=22)$ had only one disorder, $22.7 \%(n=25)$ had two and $10.9 \%(n=12)$ had three or more.

To analyze the variables associated with dual diagnosis, the Poisson regression was used. It was found that the DD was significantly higher in participants who presented risk of suicide $[p<0.00 ; P R=1.50$ (1.32 to 1.70)], attempted suicide $[p<0.04 ; P R=1.45(1.27$ to 1.65$)]$ and illegal acts $[p<0.05$; $P R=1.13$ (1.00 to 1.27)]. It was found that the consumption of crack, although not being the only drug of abuse, had a higher presence rate of major depressive episode $[p<0.03$; $P R=1.15$ (1.01 to 1.31)] and antisocial personality disorder $[p$ $=0.03 ; P R=1.13(1.00$ to 1.26$)]$.

\section{DISCUSSION}

This study identified sociodemographic differences between users of legal and illegal drugs (group 3), alcoholics (group 2) and abstinent (group 1). The main findings of this research found that dual diagnosis, risk and suicide attempts occurred more frequently in group 3 than in group 2 . The most frequent psychiatric disorder in the three groups was depression. The antisocial personality disorder and depression were related to the use of crack. It was found that the onset of substance use occurred in adolescence, the use of multiple drugs simultaneously, and the crack as the most used illicit drug.

The results of this research showed that the sociodemographic characteristics of the sample analyzed were similar to other studies. These results were evidenced by the relative similarity with other studies Regarding gender ${ }^{7,12,22}$, Marital 1,12,22,23 status, education $n^{7,12,22,23}$ employment and illegal acts ${ }^{12,24}$.

The predominance of single and separated/divorced people suggests that the search for drugs, the effects of drug use and the devaluation of family life affect the marital bonds ${ }^{23}$. In relation to education, substance use causes truancy ${ }^{23}$, and truancy consists of a risk factor for drug use ${ }^{25}$. In this scenario, the absence of professional qualification ${ }^{23,26}$ and the difficulty to reintegrate former drug users in the labor market ${ }^{26}$ contribute to unemployment in this population. 
Table 1. Sociodemographic profile of the sample, divided into groups according to the type of substance consumed - Metropolitan region of João Pessoa/Brazil, 2014

\begin{tabular}{|c|c|c|c|c|c|c|c|c|}
\hline \multirow{3}{*}{ Variable } & \multicolumn{6}{|c|}{ Groups } & & \\
\hline & \multicolumn{2}{|c|}{$\begin{array}{c}\text { Group } 1 \\
\text { (Abstinent users, except for tobacco) }\end{array}$} & \multicolumn{2}{|c|}{$\begin{array}{c}\text { Group 2 } \\
\text { (Alcohol users) }\end{array}$} & \multicolumn{2}{|c|}{$\begin{array}{c}\text { Group 3 } \\
\text { (Users of alcohol and other drugs) }\end{array}$} & \multicolumn{2}{|c|}{ Total group } \\
\hline & N & $\%$ & N & $\%$ & N & $\%$ & N & $\%$ \\
\hline TOTAL & 35 & 31.8 & 36 & 32.7 & 39 & 35.5 & 110 & 100 \\
\hline Age: Mean + SD & 49.11 & $\mathrm{DP}=10.78$ & 44.7 & $\mathrm{DP}=9.47$ & 32.51 & $\mathrm{DP}=9.94$ & 41.73 & $\mathrm{DP}=12.25$ \\
\hline \multicolumn{9}{|l|}{ Genre } \\
\hline Male & 32 & 91.4 & 32 & 88.9 & 34 & 87.2 & 98 & 89.1 \\
\hline Female & 3 & 8.6 & 4 & 11.1 & 5 & 12.8 & 12 & 10.9 \\
\hline Colour & 2 & 5.7 & 2 & 5.6 & 5 & 12.8 & 09 & 8.2 \\
\hline White & 22 & 62.9 & 22 & 61.1 & 20 & 50.3 & 64 & 58.2 \\
\hline Black & 11 & 31.4 & 12 & 33.3 & 14 & 35.9 & 37 & 33.6 \\
\hline \multicolumn{9}{|l|}{ Mulato } \\
\hline \multicolumn{9}{|l|}{ Marital status } \\
\hline Single & 17 & 48.6 & 13 & 36.1 & 26 & 66.7 & 56 & 51 \\
\hline Married/Common-law marriage & 10 & 28.1 & 8 & 22.2 & 2 & 5.1 & 30 & 27.2 \\
\hline Divorced/Separated & 07 & 20 & 15 & 41.7 & 11 & 28.2 & 23 & 20.9 \\
\hline Widow & 01 & 2.9 & 00 & 00 & 00 & 00 & 01 & 0.9 \\
\hline \multicolumn{9}{|l|}{ Education } \\
\hline Up to 9 years of study & 19 & 54.3 & 25 & 69.4 & 28 & 71.8 & 72 & 65.5 \\
\hline More than 9 years of study & 16 & 45.7 & 11 & 30.6 & 11 & 28.2 & 38 & 34.5 \\
\hline \multicolumn{9}{|l|}{ Occupation } \\
\hline Student & 01 & 2.9 & 01 & 2.8 & 02 & 5.1 & 04 & 3.6 \\
\hline Worker (Formal or informal) & 11 & 31.4 & 17 & 47.2 & 11 & 28.2 & 39 & 35.4 \\
\hline Unemployed & 12 & 34.3 & 10 & 27.8 & 19 & 48.7 & 41 & 37.2 \\
\hline Retired & 11 & 31.4 & 08 & 22.2 & 07 & 17.9 & 26 & 23.6 \\
\hline \multicolumn{9}{|l|}{ Income: n (\%) } \\
\hline No income & 19 & 54.3 & 17 & 47.2 & 22 & 56.4 & 58 & 52.7 \\
\hline Up to 1 minimum wage & 07 & 20 & 09 & 25 & 08 & 20.5 & 24 & 21.8 \\
\hline More than 2 minimum wages & 09 & 25.7 & 09 & 25 & 07 & 17.9 & 25 & 22.7 \\
\hline Governmental aid & 00 & 00 & 01 & 2.8 & 02 & 5.1 & 03 & 2.7 \\
\hline \multicolumn{9}{|l|}{ Criminal acts } \\
\hline Yes & 13 & 37.1 & 16 & 44.4 & 24 & 61.5 & 53 & 48.2 \\
\hline No & 22 & 62.9 & 20 & 55.6 & 15 & 38.5 & 57 & 51.8 \\
\hline \multicolumn{9}{|l|}{ Frequency in the service } \\
\hline 1 day & 03 & 8.6 & 00 & 00 & 02 & 5.1 & 05 & 4.5 \\
\hline 2 days & 08 & 22.9 & 06 & 18.2 & 05 & 12.8 & 19 & 17.3 \\
\hline 3 days or more & 22 & 62.9 & 26 & 72.2 & 24 & 61.5 & 72 & 65.5 \\
\hline Inmate & 00 & 00 & 01 & 03 & 02 & 5.1 & 03 & 2.7 \\
\hline No fixed frequency & 02 & 5.7 & 03 & 9.1 & 06 & 15.4 & 11 & 10 \\
\hline \multicolumn{9}{|l|}{ Previous treatment for SUD } \\
\hline Yes & 19 & 54.3 & 20 & 55.6 & 23 & 59 & 62 & 56.4 \\
\hline No & 16 & 45.7 & 16 & 44.4 & 16 & 41 & 48 & 43.6 \\
\hline
\end{tabular}


Table 2. Presence of psychiatric disorders and suicide risk according to the division of the groups - Metropolitan region of João Pessoa/ Brazil, 2014

\begin{tabular}{|c|c|c|c|c|c|}
\hline \multirow{3}{*}{ Variable } & \multicolumn{3}{|c|}{ Groups } & \multirow[b]{2}{*}{ Total group } & \multirow{3}{*}{ Value of $p$} \\
\hline & $\begin{array}{c}\text { Group } 1 \\
\text { (Abstinent users, except } \\
\text { for tobacco) }\end{array}$ & $\begin{array}{c}\text { Group2 } \\
\text { (Alcohol users) }\end{array}$ & $\begin{array}{l}\text { Group } 3 \\
\text { (Users of alcohol and } \\
\text { other drugs) }\end{array}$ & & \\
\hline & $\%$ & $\%$ & $\%$ & $\%$ & \\
\hline TOTAL & 31.8 & 32.7 & 35.5 & 100 & \\
\hline Presence of PD: & 37.1 & 60 & 71.8 & & $\begin{array}{l}\mathrm{p}^{(1)}<0.01 \\
\chi^{2}=9.23\end{array}$ \\
\hline \multicolumn{6}{|l|}{ Mood disorders } \\
\hline Current major depressive episode & 22.9 & 52.8 & 56.4 & 44.5 & $\begin{array}{c}\mathrm{p}^{(1)}<0.007 \\
\chi^{2}=9.87\end{array}$ \\
\hline Psychotic syndrome lifetime & 2.9 & 5.7 & 12.8 & 7.3 & $\begin{array}{l}p^{(1)}<0.22 \\
\chi^{2}=2.94\end{array}$ \\
\hline \multicolumn{6}{|l|}{ Anxious disorders } \\
\hline Social phobia & 2.9 & 11.1 & 10.3 & 8.2 & $\begin{array}{l}\mathrm{p}^{(1)}<0.37 \\
\chi^{2}=1.95\end{array}$ \\
\hline Obsessive-compulsive disorder & 2.9 & 5.7 & 2.6 & 3.6 & $\begin{array}{l}\mathrm{p}^{(1)}<0.75 \\
\chi^{2}=0.56\end{array}$ \\
\hline Generalized anxiety disorder & 2.9 & 17.1 & 17.9 & 12.7 & $\begin{array}{l}\mathrm{p}^{(1)}<0.10 \\
\chi^{2}=4.53\end{array}$ \\
\hline Panic disorder with or without agoraphobia & 00 & 5.7 & 7.7 & 4.5 & $\begin{array}{l}\mathrm{p}^{(1)}<0.26 \\
\chi^{2}=2.64\end{array}$ \\
\hline Agoraphobia without panic disorder & 2.9 & 8.6 & 7.7 & 6.4 & $\begin{array}{l}\mathrm{p}^{(1)}<0.58 \\
\chi^{2}=1.07\end{array}$ \\
\hline Post-traumatic stress & 8.6 & 14.3 & 12.8 & 11.8 & $\begin{array}{l}\mathrm{p}^{(1)}<0.76 \\
\chi^{2}=0.54\end{array}$ \\
\hline Antisocial personality disorder & 5.7 & 2.9 & 23.1 & 10.9 & $\begin{array}{c}\mathrm{p}^{(1)}<0.009 \\
\chi^{2}=9.36\end{array}$ \\
\hline \multicolumn{6}{|l|}{ Suicide } \\
\hline Risk of suicide & 5.7 & 20 & 33.3 & 20 & $\begin{aligned} \mathrm{p}^{(1)} & =<0.01 \\
\mathrm{x}^{2} & =8.80\end{aligned}$ \\
\hline Attempted suicide & 31.4 & 41.7 & 46.2 & 40 & $\begin{array}{l}\mathrm{p}^{(1)}<0.42 \\
\mathrm{X}^{2}=1.72\end{array}$ \\
\hline
\end{tabular}

$\left.{ }^{*}\right)$ : Significative difference at the level of $5.0 \%$.

(1): Using Pearson's chi-square test.

Users who consumed licit and illicit drugs had a higher percentage of dual diagnosis, compared to alcoholics. In the United States ${ }^{14}$, a research on DD with 465 individuals hospitalized for drug treatment and it was found that $60.6 \%$ had DD, including mood, anxiety and personality disorders, being depression the most prevalent (32.5\%). In Spain ${ }^{27}$, doctors working in drug users assistance interviewed 2.361 users, of which $33.8 \%$ had DD, predominantly depression (21.6\%). The prevalence of more than one PD in drug users was also reported by these researchers ${ }^{15,27}$. We believe that current research is strengthened because it corroborates previous large-scale studies, favoring the validity of results found.

The risk of suicide was associated with SUD ${ }^{28,29}$ with the consumption of cocaine ${ }^{29-33}$ and crack $^{29,30}$. The risk of suicide in drug users may be due to decreased central serotonergic function, the control alterations in impulse control and aggressivenes $\mathrm{s}^{28}$. In addition, assumptions supporting the relationship between suicide risk with consumption of substances, in which the latter variable can damage personal relationships increasing the risk of suicide; cause mood swings, depression or suicidal ideation, inducing suicide attempts; and impair judgment, increasing the risk of suicide ${ }^{33}$.

Depression was the most common psychiatric disorder among the three groups. Regarding the comorbid SUD, depression has been associated with treatment dropout, with the worst prognosis after treatment ${ }^{34}$, with recidivism ${ }^{34-36}$, besides increasing the likelihood of overdosing ${ }^{34}$.

The results of this study were similar for the presence of major depressive episode (MDE) and antisocial personality disorder (ASPD) among crack and cocaine users ${ }^{24}$. Being ASPD related to the involvement of crack users with crime, theft, robbery, drug trafficking ${ }^{30,37}$, as well as behaviors of physical aggression, impulsivity, delinquency and high propensity for crime $^{30}$. 
Participants presented the first drug use in adolescence. Drug use in adolescents cause lasting brain changes, increases vulnerability to SUD and is associated with later psychiatric comorbidities ${ }^{11}$. Friends influence the initiation and progression of substance use, increasing by 8.6 times the chances of consuming illicit drugs when compared to adolescents who did not have drug users as friends ${ }^{38}$.

The family culture of drug use is also considered a vulnerability factor for the SUD 2 in adolescence and adult life ${ }^{39}$, because it presents itself as a stimulus for experimentation and continuity of consumption ${ }^{40}$. Interventions within the family contribute to stop the consumption and prevent further damage ${ }^{39}$.

Confirming our initial hypothesis, alcohol was the most consumed substance, same result as obtained in previous studies of national coverage carried out in Brazil ${ }^{6}$ and in the United States ${ }^{5}$. In contrast, the consumption of crack was superior to marijuana, reported in these studies ${ }^{5,6}$ as the most prevalent illicit drug. It is assumed that the prevalence of crack may have occurred through the regional context that facilitates access to substance ${ }^{41}$, its most intense effects ${ }^{24}$ and the low commercial value of this drug $^{42}$, which favors the choice due to the low income of the population studied.

There is a necessity for greater attention to crack users due to their accelerated process of physical and mental deterioration ${ }^{42}$, severe pattern of consumption ${ }^{30}$, higher rates of social problems, increased use of health services ${ }^{30-43}$ and the presence of psychiatric comorbidities ${ }^{39}$, besides involvement in violent and illegal activities ${ }^{30,39}$

Regarding the use of marijuana, the occurrence of brain damage has been found including cognitive alterations, deficits in verbal learning and on the short-term memory ${ }^{31}$, in addition to being the gateway to the consumption of more dangerous drugs ${ }^{44}$. However, few users have reported the desire to cease the use of this substance ${ }^{43}$.

The use of multiple substances was identified in previous research ${ }^{14,23}$. When describing the sociodemographic profile of 350 drug users in treatment, it was noticed that $78.3 \%$ ( $n=99$ ) were polyusers ${ }^{23}$; and when examining the psychiatric comorbidities with 465 users in inpatient settings, it was observed that $27.2 \%$ used two substances, $6.3 \%$ three substances and $3.0 \%$ used four or more drugs ${ }^{14}$.

The polyusers use drugs in parallel or in a sequential way $^{2,30}$ for different reasons as to maximize the positive effects of drugs, to reduce the undesirable effects $2,23,30$ or as a substitution when their drug of choice is not available $e^{2,30}$. The combination of different drugs may increase the risk of overdose, negatively impact the outcome of treatment2,30 and increase the prevalence of dual diagnosis, as seen in the results of this research.

The dynamic behavior of legal and illegal drugs users has been linked to the use of previous treatments, generating high cost to the health system ${ }^{45}$. Such dynamic courses with the establishment/with the formation/with a vicious cycle formed by the compulsive quest for the substance, for treatment in health facilities, noncompliance with treatment, relapses and treatment failures ${ }^{46}$.

Based on the above considerations, it was found that drug users in treatment showed significant frequency of dual diagnosis, risk and suicide attempts, showing the importance of investigating these variables in clinical practice. The prevalence of crack may reflect increased use of this substance in the country or a predominance because of the study area. When identified the use of crack, it is suggested, according to the results obtained, to investigate the presence of antisocial personality disorder and depression.

The limitation of this study may relate to the use time period restriction of psychoactive substances in the past three months. However, such conduct is justified by the methodological choice of the ASSIST instrument.

\section{CONCLUSION}

The illicit drug users had a higher prevalence of dual diagnosis showing the severity of this clinical condition. Therefore, it is considered essential that this clinical reality is included in intervention strategies in order to decrease the negative effects of consumption of these substances and provide better quality of life for these people.

\section{INDIVIDUAL CONTRIBUTIONS}

Mariana Bandeira Formiga - Substantial contributions to conception and design, acquisition of data or analysis and interpretation of data; drafting, revision and conclusion of the article after suggestion of all co-authors.

Selene Cordeiro Vasconcelos - Substantial contributions to conception and design, analysis and interpretation of data; drafting and revision of the article.

Melyssa Cavalcanti Galdino and Murilo Duarte da Costa Lima - Substantial contributions to conception and design, analysis and interpretation of data; drafting of the article or its critical revision for important intellectual content.

All of the authors read and approved the final version.

\section{CONFLICTS OF INTEREST}

No conflicts of interest between authors.

\section{SOURCE OF FUNDING}

National Counsel for Scientific and Technological Development (CNPq), through the master's scholarship consent to the first author. 


\section{ACKNOWLEDGEMENTS}

The team working in the two centers specialized in drug treatment, Psychosocial Care Center for Alcohol and Other Drugs (CAPSad).

\section{REFERENCES}

1. APA - American Psychiatric Association. Manual diagnóstico e estatístico de transtornos mentais. 5a ed. Porto Alegre: Artmed; 2014.

2. UNODC - United Nations Office on Drugs and Crime. World Drug Report, 2014. United Nations publication: 2014, Sales No. E.14.XI.7.

3. WHO - World Health Organization. Global Status Report on Alcohol. Geneva: Department of Mental Health and Substance Abuse; 2004.

4. EMCDDA - Observatório Europeu da Droga e da Toxicodependência. Relatório Europeu sobre Drogas 2014: Tendências e evoluções. Portugal: Lisboa; 2014.

5. Substance Abuse and Mental Health Services Administration. Results from the $2012 \mathrm{Na}-$ tional Survey on Drug Use and Health: Summary of National Findings (NSDUH). Rockville, MD: Substance Abuse and Mental Health Services Administration; 2013.

6. Laranjeira R, organizador. II Levantamento Nacional de Álcool e Drogas (II LENAD) 2012. São Paulo: Instituto Nacional de Ciência e Tecnologia para Políticas Públicas de Álcool e Outras Drogas (INPAD), Unifesp; 2013.

7. Arias F, Szerman N, Vega P, Mesias B, Basurte I, Morant C, et al. Cocaine abuse or dependency and other pyschiatric disorders. Madrid study on dual pathology. Rev Psiquiatr Salud Ment. 2013;6(3):121-8.

8. Lai HM, Huang QR. Comorbidity of mental disorders and alcohol- and drug-use disorders: analysis of New South Wales inpatient data. Drug Alcohol Rev. 2009;28(3):235-42.

9. OEDT - Observatório Europeu da Droga e da Toxicodependência. Comorbilidade - 0 consumo de drogas e as perturbações mentais. Lisboa, Portugal; 2004.

10. Regier DA, Farmer ME, Rae DS, Locke BZ, Keith SJ, Judd LL, et al. Comorbidity of mental disorders with alcohol and other drug abuse. Results from the Epidemiologic Catchment Area (ECA) Study. JAMA. 1990;264(19):2511-8.

11. Langås AM, Malt UF, Opjordsmoen S. Comorbid mental disorders in substance users from a single catchment area - a clinical study. BMC Psychiatry. 2011;11:25.

12. Costa MLP, Oliveira LCM. Comorbidities of mental and behavioral disorders in chemically dependent patients in different periods of abstinence. J Bras Psiquiatr. 2012;61(3):139-47.

13. Vergara-Moragues E, González-Saiz F, Lozano-Rojas 0, Fernández-Calderón F, VerdejoGarcía A, Betanzos-Espinosa P, et al. Relación entre la comorbilidad psicopatológica y las variables de resultados en dependientes de cocaína tratados en comunidad terapéutica. Adicciones. 2013;25(2):128-36

14. Chen KW, Banducci AN, Guller L, Macatee RJ, Lavelle A, Daughters SB, et al. An examination of psychiatric comorbidities as a function of gender and substance type within an inpatient substance use treatment program. Drug Alcohol Depend. 2011;118(2-3):92-9.

15. Torrens M, Gilchrist G, Domingo-Salvany A; psyCoBarcelona Group. Psychiatric comorbidity in illicit drug users: substance-induced versus independent disorders. Drug Alcohol Depend. 2011;113(2-3):147-56.

16. Herrero MJ, Domingo-Salvany A, Torrens M, Brugal MT; ITINERE Investigators. Psychiatric comorbidity in young cocaine users: induced versus independent disorders. Addiction. 2008;103(2):284-93

17. Szerman N, Lopez-Castroman J, Arias F, Morant C, Babín F, Mesías B, et al. Dual diagnosis and suicide risk in a Spanish outpatient sample. Subst Use Misuse. 2012;47(4):383-9.

18. Chambers RA. Adult hippocampal neurogenesis in the pathogenesis of addiction and dual diagnosis disorders. Drug Alcohol Depend. 2013;130(1-3):1-12.

19. Humeniuk R, Poznyak V. ASSIST Teste de triagem para álcool, tabaco e substâncias: guia para uso na atenção primária à saúde: Versão preliminar 1.1 / Rachel Humeniuk; Vladmir Poznyak; tradução Telmo Mota Ronzani; supervisão da tradução Maria Lucia 0. Souza Formigoni, Roseli Boerngen de Lacerda; revisão Úrsula Bueno do Prado Guirro. São Paulo: OMS, 2004, 60p
20. Henrique IFS, De Micheli D, Lacerda RB, Lacerda LA, Formigoni MLOS. Validação da versão brasileira do teste de triagem do envolvimento com álcool, cigarro e outras substâncias (ASSIST). Rev Assoc Med Bras. 2004;50(2):1-8.

21. Amorim P. Mini International Neuropsychiatric Interview (MINI): validação de entrevista breve para diagnóstico de transtornos mentais. Rev Bras Psiquiatr. 2000;22(3):106-15.

22. Freitas RM, Silva HRR, Araújo DS. Resultados do acompanhamento dos usuários do Centro de Atenção Psicossocial - Álcool e Drogas (Caps-AD). SMAD Rev Eletrônica Saúde Mental Álcool Drog. 2012;8(2):56-63.

23. Capistrano FC, Ferreira ACZ, Silva TL, Kalinke LP, Maftum MA. Perfil sociodemográfico e clínico de dependentes químicos em tratamento: análise de prontuários. Esc Anna Nery. 2013;17(2):234-41.

24. Vasconcelos SC, dos Santos AR, Guerra ALAG. Psychiatrics disorders in crack and cocaine addicts. Am J Nurs. 2014;2(3):31-7.

25. Henry KL, Thornberry TP. Truancy and escalation of substance use during adolescence. J Stud Alcohol Drugs. 2010;71(1):115-24.

26. van der Meer SanchezZ, Nappo SA. Sequência de drogas consumidas por usuários de crack e fatores interferentes. Rev Saúde Pública. 2002;36(4):420-30.

27. Gual A. Dual diagnosis in Spain. Drug Alcohol Rev. 2007;26(1):65-71.

28. Bessa MA. Suicídio e álcool e drogas. Debates psiquiatria hoje. 2010;2(1):19-20.

29. Ores LDC, Quevedo LDA, Jansen K, Carvalho ABD, Cardoso TA, Souza LDDM, et al. Risco de suicídio e comportamentos de risco à saúde em jovens de 18 a 24 anos: um estudo descritivo. Cad Saude Publica. 2012;28(2):305-12.

30. Paim Kessler FH, Barbosa Terra M, Faller S, Ravy Stolf A, Carolina Peuker A, Benzano D; Brazilian ASI Group, Pechansky F. Crack users show high rates of antisocial personality disorder, engagement in illegal activities and other psychosocial problems. Am J Addict. 2012;21(4):370-80

31. Almeida PP, Novaes MAFP, Bressan RA, Lacerda ALT. Revisão: funcionamento executivo e uso de maconha. Rev Bras Psiquiatr, 2008;30(1):69-76.

32. Vaszari JM, Bradford S, Callahan O'Leary C, Ben Abdallah A, Cottler LB. Risk factors for suicidal ideation in a population of community-recruited female cocaine users. Compr Psychiatry. 2011;52(3):238-46.

33. Pompili M, Serafini G, Innamorati M, Biondi M, Siracusano A, Di Giannantonio, et al. Substance abuse and suicide risk among adolescents. Eur Arch Psychiatry Clin Neurosci. 2012;262(6):469-85.

34. Johnson JE, O'Leary CC, Striley CW, Abdallah AB, Bradford S, Cottler LB. Effects of major depression on crack use and arrests among women in drug court. Addiction. 2011;106(7):1279-86.

35. Bartoli F, Carrà G, Brambilla G, Carretta D, Crocamo C, Neufeind J, et al. Association between depression and non-fatal overdoses among drug users: a systematic review and meta-analysis. Drug Alcohol Depend. 2014;134:12-21.

36. Samet S, Fenton MC, Nunes E, Greenstein E, Aharonovich E, Hasin D. Effects of independent and substance-induced major depressive disorder on remission and relapse of alcohol, cocaine and heroin dependence. Addiction. 2013;108(1):115-23.

37. Guimarães CF, Santos DVV, Freitas RC, Araujo RB. Perfil do usuário de crack e fatores relacionados à criminalidade em unidade de internação para desintoxicação no Hospital Psiquiátrico São Pedro de Porto Alegre (RS). Rev Psiquiatr Rio Gd Sul. 2008;30(2):101-8.

38. Cardoso LRD, Malbergier A. A influência dos amigos no consumo de drogas entre adolescentes. Estud Psicol (Campinas). 2014;31(1):65-74.

39. Seleghim MR, Oliveira MLF. Influência do ambiente familiar no consumo de crack em usuários. Acta Paul Enferm. 2013;26(3):263-8.

40. Seleghim MR, Inoue KC, Santos JAT, Oliveira MLF. Aspectos da estrutura familiar de jovens usuários de crack: um estudo do genograma. Ciênc Cuid Saúde. 2012:10(4):795-802.

41. Carlini EA, Galduróz JC, Noto AR, Carlini CM, Oliveira LG, Nappo SA, et al. II Levantamento Domiciliar sobre o Uso de Drogas Psicotrópicas no Brasil: estudo envolvendo as 108 maiores cidades do país, 2005. São Paulo: Cebrid - Centro Brasileiro de Informações Sobre Drogas Psicotrópicas/Unifesp - Universidade Federal de São Paulo; 2007.

42. Vargens RW, Cruz MS, Santos MA. Comparação entre usuários de crack e de outras drogas em serviço ambulatorial especializado de hospital universitário. Rev Latino-Am Enfermagem. 2011;19(spe):804-12. 
43. Horta RL, Horta BL, Rosset AP, Horta CL. Perfil dos usuários de crack que buscam atendimento em Centros de Atenção Psicossocial. Cad Saude Publica. 2011;27(11):2263-70.

44. Agrawal A, Lynskey MT. Cannabis controversies: how genetics can inform the study of comorbidity. Addiction. 2014;109(3):360-70.
45. Duarte PCAV, Stempliuk VA, Barroso LP. Relatório brasileiro sobre drogas. Brasília: Secretaria Nacional de Políticas sobre Drogas (SENAD); 2009.

46. Medeiros R. Construção social das drogas e do crack e as respostas institucionais e terapêuticas instituídas. Saude Soc. 2014;23(1):105-17. 